\title{
ESSENTIAL OIL AND CHEMICAL CONESTITUENTS OF FENNEL PLANTS AS AFFECTED BY COMPOST/NPK AND BIOFERTILIZATION TREATMENTS
}

\author{
F.S. Badran ${ }^{*}$, E.T. Ahmed*, E.A. El-Ghadban ${ }^{* *}$ and A.M. Ayyat ${ }^{* * *}$ \\ * Hort. Dept., Fac. Agric., Minia Univ., Egypt. \\ ** Medicinal and Aromatic Plants Res. Dept., Hort. Res. Inst., ARC, Giza, Egypt. \\ *** Fac. Agric., Beni-Suef Univ., Egypt.
}

\begin{abstract}
A field experiment was conducted during the two successive seasons of 2012/2013 and 2013/2014 to explore the effect of compost/NPK and biofertilization treatments on essential oil, photosynthetic pigments and herb NPK content of fennel plants.

Obtained results revealed that the best three essential oil characteristics (essential oil \%, essential oil yield per plant and per feddan), photosynthetic pigments (chlorophylls a, b and carotenoids) and herb content of $\mathrm{N}, \mathrm{P}$ and $\mathrm{K}$ values were obtained due to the use of the full dose of mineral NPK, $1 / 4$ compost $+3 / 4$ NPK dose or $1 / 2$ compost $+1 / 2$ NPK dose with no significant differences being detected between such three fertilization treatments. Concerning biofertilization treatments, all of the prementioned essential oil determinations, photosynthetic pigments and herb NPK content traits were considerably augmented due to the dual treatment (Minia Azotein + compositions values were given by fertilizing fennel plants with the full dose of mineral NPK, $25 \%$ compost $+75 \%$ NPK or $50 \%$ compost $+50 \%$ NPK in combination with dual biofertilizer treatments (Minia Azotein + phosphorein).

It is recommended, to supply fennel plants with $50 \%$ compost + $50 \%$ NPK in combination with the dual biofertilization treatment (Minia Azotein + phosphorein), from the environmental and economical point of view, in order to maximize the fruit essential oil productivity.
\end{abstract}

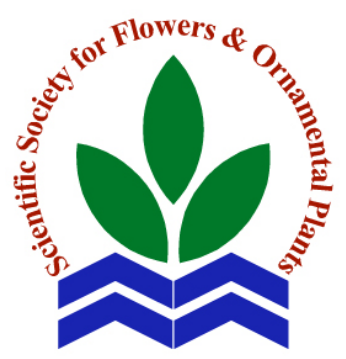

Scientific J. Flowers \& phosphorein) followed by Minia Azotein, while phosphorein gave the Ornamental Plants, least values. In regard to the interaction gave between the, two 4(2):187-197 (2017). involved factors, the highest volatile oil determinations and chemical

Received:

15/3/2017

Accepted:

3/4/2017

Key words: Foeniculum vulgare, compost, NPK, biofertilization, essential oil, chemical constituents.

\section{INTRODUCTION}

One of the widely cultivate aromatic and medicinal plants in Egypt is Foeniculum vulgare, Miller (fennel) plant. It is a common winter annual herbaceous plant grown successfully in middle Egypt region and belonging to Fam. Apiaceae and considered as one of the ancient Egyptian herbs. Its fruits are used in medicinal folklore, bakery and food industry and the essential oil (2.5-5.0\% of the fruits) is involved in different pharmaceutical purposes.

Many investigators revealed the effective role of organic fertilization treatments, from different sources, on promoting essential oil parameters, photosynthetic pigments and/or N, P and $\mathrm{K}$ contents of various aromatic seed 


\section{F.S. Badran et al.}

plants. Examples are Khater (2001) and Abd El-Naeem (2008) on caraway; Rashed (2002) on three aromatic seed crops; Younis et al. (2004) on Khella; Abd El-Gawad (2007) and Abdalla (2009) on coriander; Hemdan (2008) and Ali et al. (2010) on anise and Helmy (2008) and Al-Shareif (2012) on Nigella sativa. In regard to mineral NPK fertilization, it was found that these treatments caused considerable augmentation in essential oil aspects, photosynthetic pigments and/ or N, $\mathrm{P}$ and $\mathrm{K}$ contents (Abd El-Kader and Ghaly, 2003 and Badran et al., 2013 on coriander; Badran et al, 2003 on anise; Salah-Eldeen, 2005 and Badran et al., 2007 on fennel and Badran et al., 2009 and Al-Shareif, 2012 on Nigella sativa). Similarly, positive effects due to $\mathrm{N}$-fixing and/or P-dissolving bacteria were found by Rashed (2002) on three aromatic seed plants; Safwat and Badran (2002) and Shalateet (2006) on cumin; Mahfouz and Sharaf-Eldin (2007) and Tanious (2008) on fennel; Abd El-Naeem (2008) on caraway and Badran et al. (2009) and Badran et al. (2012) on Nigella sativa. So, the present investigation aimed to reach the most proper compost/NPK treatment in combination with biofertilizer treatment for producing the highest essential oil of fennel plants.

\section{MATERIALS AND METHODS}

This trial was carried out during the two successive seasons of 2012/2013 and 2013/2014 at Mattay, Minia Governorate, Egypt to investigate the effect of compost/NPK and biofertilizer treatments on essential oil parameters and some chemical constituents of fennel plants.

Fruits of fennel were sown on the last week of Oct. of both seasons in $3 \times 3.60$ meter plots with $60 \mathrm{~cm}$ distance between the rows and $50 \mathrm{~cm}$ between hills within each row. So, each plot contained 6 rows and 36 hills (2 plants/hill). Plants were thinned twice, 3 weeks from planting date and 2 weeks followed as usual. Physical and chemical properties of the soil are shown in Table (a).
A complete randomized block design following the split-plot arrangement, in three replicates, was executed in this experiment with six compost/NPK treatments in the main plots (A) i.e. control, compost (7.5 ton/fed), $3 / 4$ compost $+1 / 4$ NPK, $1 / 2$ compost + $1 / 2$ NPK, $1 / 4$ compost $+3 / 4$ NPK and full dose of NPK. The full dose of mineral NPK was added at the rate of $200 \mathrm{~kg} / \mathrm{fed}$ ammonium nitrate, 33.5\% N; $150 \mathrm{~kg} /$ fed calcium superphosphate, $15.5 \% \mathrm{P}_{2} \mathrm{O}_{5}$ and $100 \mathrm{~kg} /$ fed potassium sulphate, $48.55 \mathrm{~K}_{2} \mathrm{O}$. While the full dose of compost (Compost El-Neel) was added at the rate of 7.5 ton/fed, with physical and chemical properties shown in Table (b).

The sub-plots (B) were control, Minia Azotein, phosphorein and Minia Azotein plus phosphorein. The mineral $\mathrm{N}$ and $\mathrm{K}$ fertilizer amounts, for each treatment were divided into 3 batches and added after the last thinning and every three weeks thereafter.

Table a. Physical and chemical analysis of the soil.

\begin{tabular}{|c|c|c|c|c|}
\hline Characters & Value & Characters & & Value \\
\hline Soil type & $\begin{array}{l}\text { Clay } \\
\text { loam }\end{array}$ & Total N (\%) & & 0.06 \\
\hline Sand (\%) & 31.70 & Avail. P (\%) & & 8.90 \\
\hline Silt (\%) & 25.60 & Exch. K (mg/11 & 0 g) & 1.46 \\
\hline Clay (\%) & 42.70 & & $\mathbf{F e}$ & 5.10 \\
\hline Org. Matt. (\%) & 1.08 & DTPA & $\mathrm{Cu}$ & 1.29 \\
\hline $\mathrm{Ca} \mathrm{CO}_{3}(\%)$ & 4.18 & Extr. (ppm) & Zn & 1.85 \\
\hline pH (1 : 2.5) & 7.86 & & Mn & 11.52 \\
\hline E.C. (mmhos/cm) & 1.08 & & & \\
\hline
\end{tabular}

Table b. Physical and chemical properties of the used compost.

\begin{tabular}{|c|c|c|c|}
\hline Properties & Value & Properties & Value \\
\hline Dry weight of $1 \mathrm{~m}^{3}$ & $450 \mathrm{~kg}$ & $\mathrm{C} / \mathrm{N}$ ratio & $18.5-14.1$ \\
\hline Fresh weight of $1 \mathrm{~m}^{3}$ & $650-700 \mathrm{~kg}$ & $\mathrm{NaCl}(\%)$ & $1.1-1.75$ \\
\hline Moisture (\%) & $25-30$ & Total P (\%) & $0.5-0.75$ \\
\hline pH (1:10) & 7.5- 8 & Total K (\%) & $0.8-1.0$ \\
\hline E.C. $(\mathrm{mmhos} / \mathrm{cm})$ & $2-4$ & $\mathrm{Fe}(\mathrm{ppm})$ & $150-200$ \\
\hline Total N (\%) & $1-1.4$ & $\operatorname{Mn}(\mathbf{p p m})$ & $25-56$ \\
\hline Org. matter ( \%) & $32-34$ & $\mathrm{Cu}$ (ppm) & $75-150$ \\
\hline Org. carbon \% & $18.5-19.7$ & Zn ppm & $150-225$ \\
\hline
\end{tabular}


While compost and phosphorus fertilizer were added during soil preparation. The two biofertilizers, Minia Azotein and phosphorein were applied to the soil twice, after 6 and 10 weeks from planting date, at the rate of $50 \mathrm{ml} /$ plant of each biofertilizer, and then plants were irrigated immediately.

Data were recorded for the three essential oil parameters, percent and yield per plant and per fed. according to the method of Gad et al. (1963) the three photosynthetic pigments, chlorophylls a, chlorophyll $b$ and carotenoids contents were estimated using the method of Fadl and SeriEldeen (1978). Also the herb contents of nitrogen, phosphorus and potassium were determined, according to Wilde et al. (1985), Chapman and Prat (1975) and Cottenie et al. (1982) respectively, by multiplying the percent of each nutrient by the corresponding herb dry weight. All obtained data were statically analyzed following the L.S.D. method at 5\% according to MSTAT-C (1986).

\section{RESULTS}

\section{Essential oil parameters:}

Obtained data in Table (1) show that the five compost/NPK treatments, namely, full dose of compost (7.5 ton/ fed), 3/4 compost + $1 / 4$ NPK, $1 / 2$ compost $+1 / 2$ NPK, $1 / 4$ compost + $3 / 4$ NPK and full dose of NPK caused noticeable and great increase in essential oil percent and yield per plant and per fed, in the two seasons, over those of control unfertilized plants. Such increase was significant due to all these five treatments for the essential oil yield per plant and per fed, but not significant only for full dose of compost in regard to essential oil percent in both seasons. Among the five examined compost/NPK treatments, each of the three essential oil parameters, was gradually increased, in ascending order, due to full dose of compost, $3 / 4$ compost $+1 / 4$ NPK, $1 / 2$ compost $+1 / 2$ NPK, $1 / 4$ compost $+3 / 4$ NPK and full dose of NPK. These results were almost identical in the two seasons as illustrated in Table (1).
The increase in essential oil yield per fed due to the use of the previously mentioned five treatments, in comparison with control treatment, reached 52.7, 86.4, 113.0, 147.3 and $195.1 \%$ in the first season; and 66.9, 97.1, 140.6, 191.4 and $228.6 \%$ respectively in the second season. The role of organic fertilization in augmenting essential oil parameters was reported by Abd El-Naeem (2008) on caraway; Hemdan (2008) on anise; Helmy (2008) and Al-Shareif (2012) on black cumin and Abdalla (2009) on coriander. While that of $3 / 4$ compost $+1 / 4$ NPK, $1 / 2$ compost $+1 / 2$ NPK, $1 / 4$ compost $+3 / 4$ NPK and full dose of NPK was insured by Badran et al. (2003) on anise; Adb El-Kader and Ghaly (2003) and Badran et al. (2013) on coriander and Badran et al. (2009) and Al-Shareif (2012) on Nigilla sativa.

Concerning biofertilization treatments, the three used ones, Minia Azotein, phosphorein and dual Minia Azotein/ phosphorein treatments caused an increase in essential oil percent and yield per plant and per fed, in both seasons, over those of control plants as shown in Table (1). The differences were significant only for the yield per plant and per fed with the highest values being given by the dual treatment (Minia Azotein + phosphorein) followed by Minia Azotein, while phosphorein gave the least values. The dual treatment increased essential oil yield/ fed by $19.4 \%$ in the first season, and by $18.4 \%$ in the second one in comparison with those of control plants as shown in Table (1). The increase in essential oil was also found on cumin (Safwat and Badran, 2002 and Shalateet, 2006); caraway (Abd El-Naeem, 2008); fennel (Tanious, 2008) and black cumin (Badran et al., 2012).

The interaction between compost / NPK treatments and biofertilization treatments was significant, in both seasons, for the three fennel essential oil parameters, percent and yield per plant and per fed, as clearly shown in Table (1). The highest overall value for the three parameters was obtained when fennel plants were fertilized with the full dose of NPK in combination with the dual 
Table 1. Effect of compost/ NPK and biofertilization treatments on essential oil determinations of fennel plants during 2012/2013 and 2013/2014 seasons.

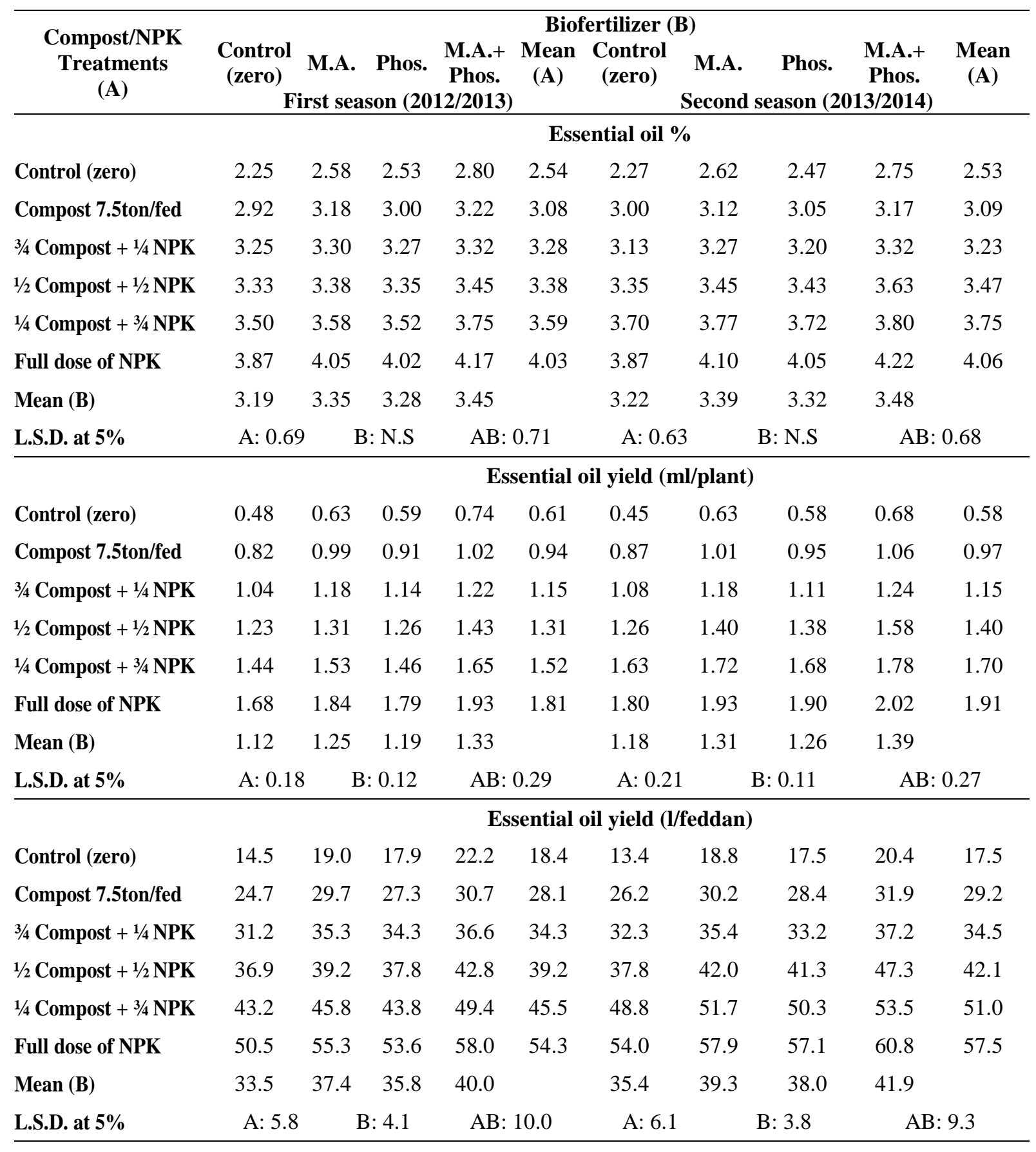


biofertilization treatment. However, from the practical, economical and environmental point of view, no significant differences were existed, in both seasons for the three essential oil parameters, between solely NPK traditional treatment and that of $1 / 2$ compost + $1 / 2$ NPK plus dual biofertilization treatment as clearly indicated in Table (1).

\section{Photosynthetic pigments:}

The three photosynthetic pigments, chlorophyll a, chlorophyll b and carotenoids contents in the leaves of fennel plants were greatly promoted in the two seasons due to the use of all five compost and/or mineral NPK fertilization treatments in comparison with those of control treatment as shown in Table (2). Most of these fertilization treatments resulted in significant differences, for control treatment. The highest values in this concern were obtained from the three treatments of all NPK dose, $1 / 4$ compost $+3 / 4$ NPK and $1 / 2$ compost $+1 / 2$ NPK with no significant being obtained between such three treatments. These results were similar in the two experimental seasons as illustrated in Table (2). In agreement with these results, in regard to organic fertilization, were the findings of Abd El-Gawad (2007) and Abdalla (2009) on coriander; Abd El-Naeem (2008) on caraway; Hemdan (2008) on anise and Al-Shareif (2012) on Nigella sativa. In relation to mineral NPK fertilization were those found by Badran et al. (2003) on anise; Salah-Eldeen (2005) and Badran et al. (2007) on fennel and Badran et al. (2009) and Al-Shareif (2012) on Nigella sativa.

In regard to biofertilization treatments, the obtained results in Table (2) showed that these treatments seemed to have slight influence on inducing the contents of chlorophyll a, chlorophyll b and carotenoids. Significant differences were detected only for chlorophyll a in the first season. Among the three biofertilization treatments, the dual one (Minia Azotein + phosphorein) surpassed the other two treatments in producing higher values of chlorophyll a and $\mathrm{b}$ and carotenoids contents in both seasons as shown in Table (2). In accordance with these findings were the results of Rashed (2002) on three aromatic seed plants; Shalateet (2006) on cumin; Abd El-Naeem (2008) on caraway; Tanious (2008) on fennel and Badran et al. (2009) on Nigella sativa.

The interaction between compost/ NPK and biofertilization treatments was significant for chlorophyll a and carotenoids contents in the two experimental seasons. However, the highest overall values for the three photosynthetic pigments were obtaind due to the full NPK, followed by $1 / 4$ compost $+3 / 4$ NPK and $1 / 2$ compost $+1 / 2$ NPK in combination with the dual Minia Azotein/phosphorein treatment as shown in Table (2).

\section{Herb Contents of N, P and K:}

Data in Table (3) showed that all five tested compost and/or NPK fertilization treatments caused significant promotion, in both first and second seasons, in each of nitrogen, phosphorus and potassium contents in the herb of fennel plants, in comparison with those of control plants. The highest increase, among these five treatments, for each one of three nutrients contents in the two seasons was attained by the full dose of NPK treatment, while the lowest increase was due to the full dose of compost treatment. Meanwhile, the three combined compost/NPK treatments gave intermediate increase as clearly illustrated in Table (3). The increase in herb $\mathrm{N}, \mathrm{P}$ and $\mathrm{K}$ contents due to $100 \%$ compost and $100 \%$ NPK treatments, respectively, came to 14.3 and $68.6 \%$ for nitrogen; 33.7 and $132.7 \%$ for phosphorus and 24.0 and $66.1 \%$ for potassium in the first season. The corresponding increase in the second season reached 17.1 and $74.2 \%$ for nitrogen; 36.5 and $138.5 \%$ for phosphorus, and 13.7 and $55.0 \%$ for potassium.

The role of organic fertilization in promoting N, P and k contents was found by Khater (2001), Rashed (2002), Younis et al. (2004), Abd El-Gawad (2007) and Ali et al. (2010) on caraway, 3 aromatic plants, Khella, coriander and anise respectively. 
Table 2. Effect of compost/ NPK and biofertilization treatments on photosynthetic pigments of fennel plants during 2012/2013 and 2013/2014 seasons.

\begin{tabular}{|c|c|c|c|c|c|c|c|c|c|c|}
\hline \multirow{3}{*}{$\begin{array}{c}\text { Compost/NPK } \\
\text { Treatments } \\
\text { (A) }\end{array}$} & \multicolumn{10}{|c|}{ Biofertilizer (B) } \\
\hline & $\begin{array}{c}\text { Control } \\
\text { (zero) }\end{array}$ & & & $\begin{array}{l}\text { M.A.+ } \\
\text { Phos. }\end{array}$ & $\begin{array}{l}\text { Mean } \\
\text { (A) }\end{array}$ & $\begin{array}{c}\text { Control } \\
\text { (zero) }\end{array}$ & M.A. & & $\begin{array}{l}\text { M.A.+ } \\
\text { Phos. }\end{array}$ & $\begin{array}{l}\text { Mean } \\
\text { (A) }\end{array}$ \\
\hline & \multicolumn{6}{|c|}{ First season $(2012 / 2013)$} & \multicolumn{4}{|c|}{ Second season $(2013 / 2014)$} \\
\hline & \multicolumn{10}{|c|}{ Chlorophyll a content (mg/g F.W.) } \\
\hline Control (zero) & 1.429 & 1.522 & 1.499 & 1.572 & 1.505 & 1.483 & 1.521 & 1.503 & 1.535 & 1.511 \\
\hline Compost 7.5ton/fed & 1.606 & 1.633 & 1.611 & 1.643 & 1.623 & 1.577 & 1.620 & 1.613 & 1.637 & 1.612 \\
\hline $3 / 4$ Compost $+1 / 4$ NPK & 1.652 & 1.673 & 1.669 & 1.687 & 1.670 & 1.659 & 1.687 & 1.675 & 1.699 & 1.680 \\
\hline $1 / 2$ Compost $+1 / 2$ NPK & 1.701 & 1.728 & 1.716 & 1.761 & 1.727 & 1.710 & 1.734 & 1.725 & 1.745 & 1.729 \\
\hline $1 / 4$ Compost + 3/4 NPK & 1.759 & 1.790 & 1.783 & 1.798 & 1.782 & 1.748 & 1.775 & 1.760 & 1.810 & 1.773 \\
\hline Full dose of NPK & 1.804 & 1.817 & 1.810 & 1.827 & 1.814 & 1.826 & 1.841 & 1.838 & 1.859 & 1.841 \\
\hline Mean (B) & 1.658 & 1.694 & 1.681 & 1.715 & & 1.667 & 1.696 & 1.686 & 1.714 & \\
\hline \multirow[t]{2}{*}{ L.S.D. at $5 \%$} & \multicolumn{3}{|c|}{ A: 0.106} & \multicolumn{2}{|c|}{ AB: 0.125} & \multicolumn{2}{|c|}{ A: 0.121} & B: N.S & \multicolumn{2}{|c|}{ AB: 0.135} \\
\hline & \multicolumn{10}{|c|}{ Chlorophyll b content (mg/g F.W.) } \\
\hline Control (zero) & 0.522 & 0.554 & 0.544 & 0.567 & 0.547 & 0.524 & 0.540 & 0.539 & 0.557 & 0.540 \\
\hline Compost 7.5ton/fed & 0.571 & 0.586 & 0.581 & 0.593 & 0.583 & 0.570 & 0.581 & 0.577 & 0.585 & 0.579 \\
\hline 3/4 Compost + 1/4 NPK & 0.597 & 0.619 & 0.615 & 0.625 & 0.614 & 0.592 & 0.613 & 0.611 & 0.637 & 0.613 \\
\hline $1 / 2$ Compost $+1 / 2$ NPK & 0.636 & 0.642 & 0.640 & 0.665 & 0.646 & 0.646 & 0.656 & 0.650 & 0.688 & 0.660 \\
\hline $1 / 4$ Compost $+3 / 4$ NPK & 0.666 & 0.677 & 0.671 & 0.697 & 0.678 & 0.692 & 0.703 & 0.694 & 0.717 & 0.701 \\
\hline Full dose of NPK & 0.704 & 0.727 & 0.715 & 0.742 & 0.722 & 0.719 & 0.733 & 0.724 & 0.768 & 0.736 \\
\hline Mean (B) & 0.616 & 0.634 & 0.628 & 0.648 & & 0.624 & 0.637 & 0.632 & 0.659 & \\
\hline \multirow[t]{2}{*}{ L.S.D. at $5 \%$} & \multicolumn{2}{|c|}{ A: 0.092} & B: N.S & \multicolumn{2}{|c|}{ AB: N.S } & \multicolumn{2}{|c|}{ A: 0.086} & B: N.S & \multicolumn{2}{|c|}{ AB: N.S } \\
\hline & \multicolumn{10}{|c|}{ Carotenoids content (mg/g F.W.) } \\
\hline Control (zero) & 0.636 & 0.654 & 0.659 & 0.679 & 0.657 & 0.641 & 0.651 & 0.660 & 0.672 & 0.656 \\
\hline Compost 7.5ton/fed & 0.683 & 0.694 & 0.696 & 0.710 & 0.696 & 0.697 & 0.713 & 0.717 & 0.729 & 0.714 \\
\hline $3 / 4$ Compost $+1 / 4$ NPK & 0.722 & 0.736 & 0.742 & 0.759 & 0.740 & 0.748 & 0.760 & 0.773 & 0.780 & 0.765 \\
\hline $1 / 2$ Compost $+1 / 2$ NPK & 0.766 & 0.774 & 0.779 & 0.798 & 0.779 & 0.792 & 0.798 & 0.813 & 0.826 & 0.807 \\
\hline $1 / 4$ Compost + 3/4 NPK & 0.842 & 0.855 & 0.868 & 0.893 & 0.865 & 0.849 & 0.856 & 0.868 & 0.875 & 0.862 \\
\hline Full dose of NPK & 0.900 & 0.923 & 0.922 & 0.940 & 0.921 & 0.915 & 0.934 & 0.949 & 0.964 & 0.940 \\
\hline Mean (B) & 0.758 & 0.773 & 0.778 & 0.797 & & 0.774 & 0.785 & 0.797 & 0.808 & \\
\hline L.S.D. at $5 \%$ & \multicolumn{2}{|c|}{ A: 0.165} & B: N.S & \multicolumn{2}{|c|}{ AB: 0.208} & \multicolumn{2}{|c|}{ A: 0.152} & B: N.S & \multicolumn{2}{|c|}{ AB: 0.172} \\
\hline
\end{tabular}


Table 3. Effect of compost/ NPK and biofertilization treatments on NPK contents of fennel plants during 2012/2013 and 2013/2014 seasons.

\begin{tabular}{|c|c|c|c|c|c|c|c|c|c|c|}
\hline \multirow{3}{*}{$\begin{array}{c}\text { Compost/NPK } \\
\text { Treatments } \\
\text { (A) }\end{array}$} & \multicolumn{10}{|c|}{ Biofertilizer (B) } \\
\hline & $\begin{array}{c}\text { Control } \\
\text { (zero) }\end{array}$ & & & $\begin{array}{l}\text { M.A.+ } \\
\text { Phos. }\end{array}$ & $\begin{array}{l}\text { Mean } \\
\text { (A) }\end{array}$ & $\begin{array}{c}\text { Control } \\
\text { (zero) }\end{array}$ & & & $\begin{array}{l}\text { M.A.+ } \\
\text { Phos. }\end{array}$ & $\begin{array}{l}\text { Mean } \\
\text { (A) }\end{array}$ \\
\hline & \multicolumn{6}{|c|}{ First season $(2012 / 2013)$} & \multicolumn{4}{|c|}{ Second season $(2013 / 2014)$} \\
\hline & \multicolumn{10}{|c|}{ Herb nitrogen content (mg/g D.W.) } \\
\hline Control (zero) & 44.6 & 51.0 & 50.1 & 55.6 & 50.3 & 44.5 & 51.4 & 50.0 & 55.5 & 50.4 \\
\hline Compost 7.5ton/fed & 55.6 & 58.0 & 57.3 & 59.2 & 57.5 & 56.1 & 59.7 & 58.9 & 61.2 & 59.0 \\
\hline 3/4 Compost + 1/4 NPK & 57.9 & 62.4 & 61.1 & 66.2 & 61.9 & 61.7 & 63.4 & 62.4 & 68.1 & 63.9 \\
\hline $1 / 2$ Compost $+1 / 2$ NPK & 65.7 & 69.0 & 67.3 & 71.4 & 68.4 & 69.3 & 72.1 & 70.6 & 73.6 & 71.4 \\
\hline $1 / 4$ Compost $+3 / 4$ NPK & 74.4 & 78.5 & 77.0 & 81.1 & 77.8 & 75.5 & 81.4 & 79.1 & 82.1 & 79.5 \\
\hline Full dose of NPK & 81.9 & 85.8 & 83.5 & 87.8 & 84.8 & 84.7 & 87.8 & 87.1 & 91.6 & 87.8 \\
\hline Mean (B) & 63.4 & 67.5 & 66.0 & 70.2 & & 65.3 & 69.3 & 68.0 & 72.0 & \\
\hline \multirow[t]{2}{*}{ L.S.D. at $5 \%$} & \multicolumn{2}{|c|}{ A: $6.2 \quad \mathrm{E}$} & 3: 6.6 & \multicolumn{2}{|c|}{ AB: 16.2} & \multicolumn{2}{|c|}{ A: 7.3} & B: 6.2 & \multicolumn{2}{|c|}{ AB: 15.2} \\
\hline & \multicolumn{10}{|c|}{ Herb phosphorus content (mg/g D.W.) } \\
\hline Control (zero) & 8.4 & 10.1 & 10.2 & 11.6 & 10.1 & 8.3 & 9.5 & 9.8 & 10.9 & 9.6 \\
\hline Compost 7.5ton/fed & 12.7 & 13.2 & 13.6 & 14.4 & 13.5 & 11.8 & 12.6 & 13.7 & 14.2 & 13.1 \\
\hline 3/4 Compost + 1/4 NPK & 14.4 & 15.4 & 15.3 & 16.7 & 15.4 & 14.5 & 14.9 & 15.0 & 15.9 & 15.2 \\
\hline $1 / 2$ Compost $+1 / 2$ NPK & 16.6 & 17.3 & 17.2 & 18.9 & 17.5 & 16.2 & 17.0 & 16.8 & 18.2 & 17.1 \\
\hline $1 / 4$ Compost + 3/4 NPK & 19.3 & 20.4 & 20.5 & 22.0 & 20.6 & 18.6 & 19.9 & 19.8 & 20.4 & 19.7 \\
\hline Full dose of NPK & 22.0 & 23.4 & 23.5 & 25.0 & 23.5 & 21.7 & 22.7 & 23.0 & 24.2 & 22.9 \\
\hline Mean (B) & 15.6 & 16.6 & 16.7 & 18.1 & & 15.2 & 16.1 & 16.3 & 17.3 & \\
\hline \multirow[t]{2}{*}{ L.S.D. at $5 \%$} & \multicolumn{3}{|c|}{ A: 3.1} & \multicolumn{2}{|c|}{ AB: 10.3} & A: 2.8 & \multicolumn{2}{|r|}{ B: N.S } & \multicolumn{2}{|c|}{ AB: 9.3} \\
\hline & \multicolumn{10}{|c|}{ Herb potassium content (mg/g D.W.) } \\
\hline Control (zero) & 70.1 & 77.5 & 74.5 & 86.8 & 77.2 & 77.6 & 86.9 & 85.0 & 92.8 & 85.6 \\
\hline Compost 7.5ton/fed & 93.3 & 96.0 & 95.0 & 98.5 & 95.7 & 93.7 & 98.4 & 97.9 & 99.1 & 97.3 \\
\hline $3 / 4$ Compost + 1/4 NPK & 96.7 & 102.0 & 100.1 & 106.7 & 101.4 & 100.1 & 101.7 & 100.2 & 106.3 & 102.4 \\
\hline $1 / 2$ Compost $+1 / 2$ NPK & 106.3 & 110.0 & 107.3 & 112.6 & 109.1 & 108.3 & 112.4 & 110.2 & 114.1 & 111.3 \\
\hline $1 / 4$ Compost + 3/4 NPK & 116.8 & 121.7 & 119.6 & 123.3 & 120.4 & 116.4 & 123.5 & 121.1 & 125.0 & 121.5 \\
\hline Full dose of NPK & 124.6 & 128.7 & 127.0 & 132.3 & 128.2 & 128.1 & 132.7 & 131.9 & 137.9 & 132.7 \\
\hline Mean (B) & 101.3 & 106.0 & 103.9 & 110.0 & & 104.0 & 109.3 & 107.9 & 112.5 & \\
\hline L.S.D. at $5 \%$ & A: 10.3 & & 3: 7.6 & AB: & 18.6 & A: 10.8 & & B: 8.1 & AB: & \\
\hline
\end{tabular}




\section{F.S. Badran et al.}

While that of NPK fertilization was recognized on anise (Badran et al., 2003); fennel (Salah-Eldeen, 2005) and (Badran et al., 2007); black cumin (Badran et al., 2009) and coriander (Badran et al., 2013).

Herb nitrogen and potassium contents were significantly increased, in the two seasons, due to the use of dual biofertilization treatment (Minia Azotein + phosphorein) as shown in Table (3). Similar observation was found for phosphorus content but with no significant differences. In addition, each of Minia Azotein and phosphorein treatments caused an increase in $\mathrm{N}, \mathrm{P}$ and $\mathrm{K}$ contents over those of control plants in both seasons, but the differences did not reach the level of significancy as indicated in Table (3). Some authors pointed out the role of biofertilization treatments in augmenting $\mathrm{N}, \mathrm{P}$ and $\mathrm{K}$ contents such as Rashed (2002) on 3 aromatic plants; Mahfouz and Sharaf-Eldeen (2007) on fennel and Badran et al. (2012) on Nigella sativa.

The interaction between compost/NPK treatments and biofertilization treatments was significant for nitrogen, phosphorus and potassium contents in the two seasons as shown in Table (3). The highest overall values were those given by the full dose of NPK treatment in combination with any one of the three biofertilization treatments. In the second place came the treatment of $1 / 4$ compost $+3 / 4$ NPK in combination with the dual biofertilization treatment, (Table, 3).

\section{DISCUSSION}

The recommended dose of mineral NPK was applied to fennel plants to be compared with some organic and (N-fixing and/or Pdissolving bacteria) commercial products (Minia Azotein and/or phosphorein). It was found that NPK treatment overcame such compost and biofertilization treatments in essential oil yield and some chemical composition. The superiority of mineral NPK fertilization could be attributed to the unique biological and physiological roles of each one of such three essential elements in plant growth and development explained by Yagodin (1984).

Nitrogen is a constituent of most organic compounds i.e. amino acids, nucleic acids (RNA and DNA) enzymes, alkaloids, vitamins, phosphatides, purine, and many energy transfer materials such as chlorophylls, ADP and ATP, Bidwall (1974) . Phosphorus which have been called the key to life is essential for cell division and for development of meristimatic tissue and it is very important for carbohydrate transformation duo to multitude of phosphorylation reaction and to energy rich phosphate bond, (Lambers et al., 2000). Potassium is important for growth and elongation probably due to its function as an osmoticum and may react synergistically with IAA; moreover, it promotes $\mathrm{CO} 2$ as simulation and translocation of carbohydrates from the leaves to storage tissues (Mengel and Kirkby, 1987).

Follet et al. (1981) summarized the positive roles of organic fertilization in the following points:

- Increasing total nitrogen, organic matters and humus in soil.

- Improving soil properties and water holding capacity.

- Faster release of essential nutrients by microbial decomposition.

Different authors such as Hedge et al. (1999) and Hauwaka (2000) explained the roles of $\mathrm{N}$ - fixing bacteria in:

- Fixation of the atmospheric $\mathrm{N}$ which caused an increment of available $\mathrm{N}$ which increase, by sequence, the formation of many metabolites.

- Protecting their host plant against plant pathogens through the production of antibacterial and antifungal substances.

The enhancing effects of P-dissolving bacteria, on the other hand, were suggested by Abdou-Elnour et al. (1996) and Hauaka (2000) and could be summarized in: 
- Producing growth hormones which promote plant growth and development.

- Establishment of strong root system is related to the level of available phosphate in the soil.

\section{REFERENCES}

Abd El-Gawad, M.H. (2007). Effect of Some Organic and Biofertilization Treatments on Vegetative Growth and Chemical Composition of Coriander Plants. Ph.D. Thesis., Fac. Agric. Minia Univ.

Abd El-Kader, H.H. and Ghaly, N.G. (2003). Effects of cutting the herb and the use of nitrobein and Phosphorein associated with mineral fertilizers on growth, fruit and oil yields and chemical composition of the essential oil of coriander plants (Coriandrum sativum, L.). J. Agric. Sci., Mansoura Univ. 28(3): 2161-2171.

Abd El-Naeem, L.A. (2008). Response of Caraway Plants to Some Organic and Biofertilization Treatments. M.Sc. Thesis, Fac. Agric., Minia Univ.

Abdalla, M.Y. (2009). Effect of organic, bio and mineral fertilization on growth, yield, oil productivity and chemical constituents of coriander plant. J. Agric. Sci., Mansoura Univ., 34(5):5195-5708.

Abdou-EInour, E.A.A; El-Sayed, A.A. and EI-Bendary, A.A. (1996). Effect of phosphate biofertilizer (phosphorein) on growth, yield and nutrient uptake of faba bean plants. J. Agric. Sci., Mansoura Univ., 21(2):477-483.

Al-Shareif, A.M. (2012). Physiological Studies on Black Cumin Plant. Ph.D. Thesis., Fac. Agric., Minia Univ.

Ali, F.S.; Zayed, G.; Saad, O.A. and AbdElmohsen, E. (2010). The effects of compost and inoculation with mycorrhize on anise plant growth. Minia $2^{\text {nd }}$ Conf. Agric. \& Environ. Sci. Agric. \& Dev., March 22-24, 20120:509-515.

Badran, F.S. and Aly, M.K. and AbdEllatif, M.Z. (2009). Response of Nigella sativa, L. plants to plant density and mineral/biofertilization treatments. The $7^{\text {th }}$ Inter. Conf. of Organic Agric., Cairo, Egypt, Dec.10-12, 2009. (Egypt. J. Agric. Res., 87(1):185-195).

Badran, F.S. and Aly, M.K. and Abd ElLatif, M.Z. (2012). Influence of NPK, biofertilizers and micronutrients on Nigella sativa, L. plants. Minia Inter. Conf. for Agric \& Irrig. In the Nile Basin Countries, March 26-29, 2012, Minia, Egypt.

Badran, F.S.; Abdalla, N.M.; Aly, M.K. and Ibrahim, S.M. (2007). Response of fennel plants to seeding rate and partial replacement of mineral NPK by biofertilization treatments, Proc. the $8^{\text {th }}$ African Crop. Sci. Conf., El Minia, Egypt, 27- 31, Oct, 2007, 8(1):417- 422.

Badran, F.S.; Attia, F.A. and Ayyat, A.M. (2013). Effect of macro/micro fertilization treatments, as well as, salicylic and ascorbic acids on growth, fruit yield and essential oil of coriander Plants grown in sandy soil. The first Assuit Inter. Conf. of Horticulture, 24$27^{\text {th }}$ Feb., 2013.

Badran, F.S.; Attia, F.A.; Ahmed, E.T. and Soliman, H.S. (2003). Effect of chemical and biological fertilization on growth, yield and oil production of anise (Pimpinella anisum, L.) plants. II. Effect of NP mineral/biofertilization and micronutrient treatments. Proc. $1^{\text {st }}$ Egypt \& Syr. Conf. for Agric. \& Food, Minia: Dec. 8-11, 2003, 1(1):103-112.

Bidwall, R.G. (1974). Plant Physiology. Macmillan Publishing Co. Inc., New York, U.S.A.

Chapman, H.D. and Pratt, P.F. (1975). Methods of Analysis for Soil, Plant and Water Calif. Univ. Division of Agric. Sci., 172-174.

Cottenie, A.; Verloo, M.; Velghe, M. and Camerlynck, R. (1982). Chemical Analysis of Plant and Soil. Laboratory of Analytical and Agro Chemistry. State Univ., Ghent, Belgium. 


\section{F.S. Badran et al.}

Fadl, M.S. and Seri El-Deen, S.A. (1978). Effect of N-benzyl adenine on photosynthetic pigments and total soluble sugars on olive seedling growth under saline conditions Res. Bull. Fac. Agric. Ain Shams Univ. 843.

Follet, R.H.; Murphy, L.S. and Donahue, R.I. (1981). Fertilizers and soil Amendments. Prentice Hall, Inc., Inqlewood Cliffs, N.J. USA.

Gad, A.M.; El-Dakhakhny, M. and Hassan, M.M. (1963). Studies on the chemical constitution of Egyptian Nigella sativa, L. oil. Planta Medica, 11:134-138.

Hauwaka, F.I. (2000). Effect of using single and composite inoculation with Azospirillum brasilense, Bacillus megatherium var., phosphaticum and Glomus marcocarpus for improving growth of Zea mays. J. Agric. Sci., Mansoura Univ., Egypt, 25(1):239-252.

Hedge, D.M.; Dwivedi, B.S. and Sudhakara B.S.S. (1999). Biofertilizers for cereal production in India, A review. Indian J. Agric. Res., 69(2):73-83.

Helmy, T.A. (2008). Effect of Organic and Biofertilization Treatments on Black Cumin Plants. M.Sc. Thesis, Fac. Agric., Minia Univ.

Hemdan, Sh.H. (2008). Effect of Some Organic and Biofertilization Treatments on Anise Plants. M.Sc. Thesis, Fac. Agric., Minia Univ.

Khater, R.M. (2001). Effect of Some Fertilizer Treatments on The Growth and Volatile Oil Yield of Carum carvi plant. M.Sc. Thesis, Fac. Agric., Zagazig Univ.

Lambers, H; Chapin, F.S. and Pons, T.L (2000). Plant Physiological Ecology. Springer-Verleg, New York Inc.

Mahfouz, S.A. and Sharaf-Eldin, M.N. (2007). Effect of mineral vs. biofertilizer on growth, yield and essential oil content of fennel (Foeniculum vulgare, Mill) In. Agro-physic. 21: 361-366.
Mengel, K. and Kirkby, A. (1987). Principles of Plant Nutrition. $4^{\text {th }}$ Ed. International Potash, Institute, Bern/Swizerland.

MSTAT-C, (1986). A software program for the design, management and analysis of agronomic research experiments. (Version 4.0) Michigan State University.

Rashed, N.M. (2002). Effect of Fertilization on The Growth and Storability of Some Aromatic Plants. M.Sc. Thesis., Fac. Agric., Kafr El-Sheikh, Tanta Univ., Egypt.

Safwat, M.S. and Badran, F.S. (2002). Efficiency of organic and biofertilizers, in comparison with chemical fertilization, on growth, yield and essential oil of cumin plants. Proc. $9^{\text {th }}$ Conf. of Medicinal and Aromatic Plants, Cairo Egypt.

Salah-Eldeen, R.M. (2005). Effect of Planting Density and Chemical Biofertilization on Vegetative Growth, Yield Oil and Chemical Composition of Fennel (Foeniculum vulgare, Mill) Plants. Ph.D. Thesis, Fac. Agric., Minia Univ.

Shalateet, Sh.G. (2006). Comparative Studies on Cumin Productivity Grown Under Traditional and Organic Cultivation Systems. M.Sc. Thesis, Fac. Agric., Minia Univ.

Tanious, C.T. (2008). Effect of Some Organic and Biofertilization Treatments on Fennel Plants. M.Sc. Thesis, Fac. Agric. Minia Univ.

Wilde, S.A.; Covey, R.P.; Lyer, J.C. and Voigt, G.K. (1985). Soil and Plant Analysis for Tree Culture. Oxford, IBH. Publishing Co., New Delhi, India.

Yagodin, B.A. (1984). Agricultural Chemistry, Part II. Publishers, Moscow, 1-66.

Younis, S.I.; Ghaly, N. and Ahmed, Sh.K. (2004). Effect of FYM and planting space on vegetative growth, active 
ingredient and chemical composition of Ammi visnaga, L. J. Agric. Sci, Mansoura Univ., 29(4):1985-1993.

\section{تأثير معاملات التسميد بالكمبوست/المعدني والحيوي على الزيت الطيار والمكونـات الكيماوية لتباتناث الثمر الثري \\ فاروق صلاح الدين بدران* ، عماد الدين توفيق احمد* ، المو افي عبده الغضبان ** و احمد محمد عياط***

$$
\begin{aligned}
& \text { * قسم البساتين، كلية الزر اعة، جامعة المنيا، مصر . }
\end{aligned}
$$

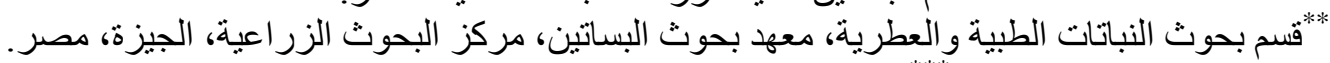

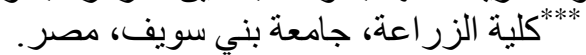

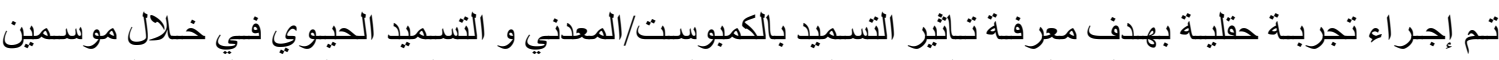

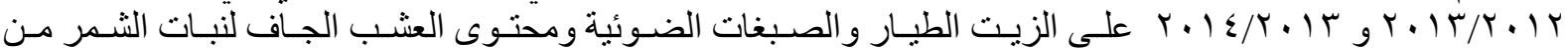

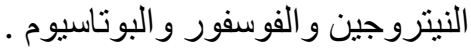

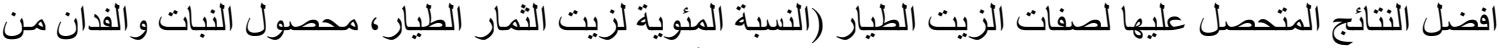

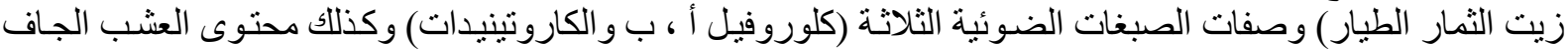

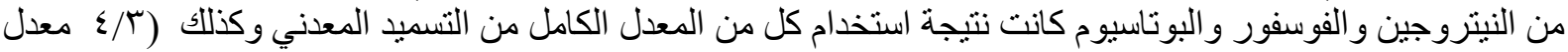

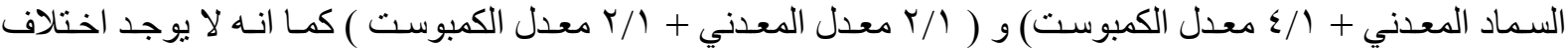

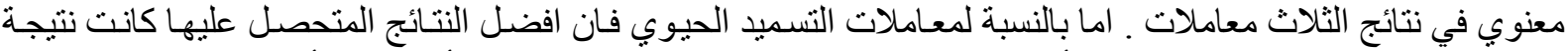

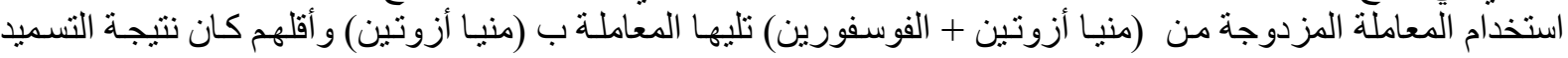

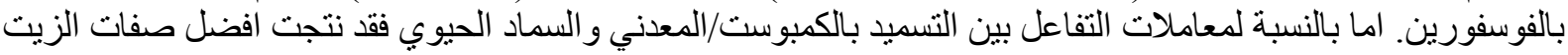

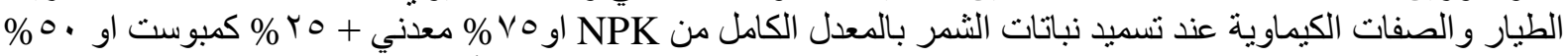

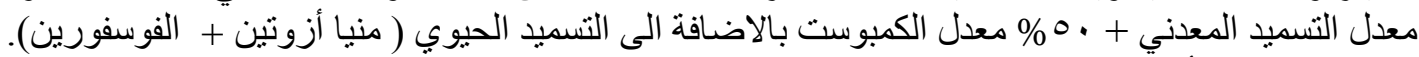

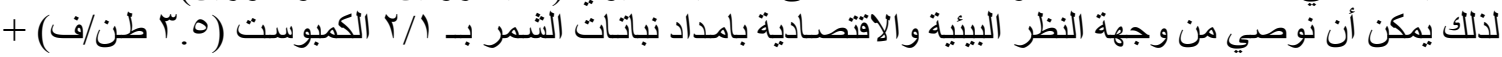

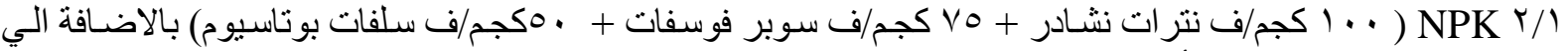
المعاملة الحيوية الثنائية (منيا أزوتين • مل للنبات + فوسفورين • مل للنبات ) وذلك بغرض تعظيم محصول الزيت

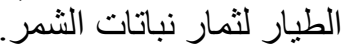


